\title{
Fish-Scale Pits with Diversion Holes Enhance Water Conservation in Semi-arid Loess Soil: Experiments with Soil Columns, Mulching, and Simulated Rainfall
}

\author{
Jiyong Zheng ${ }^{1,2} \cdot \mathrm{Ke} \mathrm{Wang}^{1,2} \cdot$ Jiangbo Ma ${ }^{1,2} \cdot \mathrm{Honghua} \mathrm{He}^{1,2} \cdot \mathrm{Yu} \mathrm{Liu}^{1}$ (D)
}

Received: 22 January 2019 / Accepted: 19 March 2019 / Published online: 25 April 2019

(C) The Author(s) 2019

\begin{abstract}
Fish-scale pits, as one of the most important ecological engineering in semi-arid areas, especially in the Loess Plateau, China, effectively reduced water and soil loss by intercepting runoff. However, the water saved by the pits is mainly accumulated in the upper soil layer and thus easily loosed by ineffective evaporation. In this study, soil column simulation experiments were conducted to observe the effects of diversion holes on soil evaporation and soil water distribution in the loessial soil under two rainfall depths and different soil surface treatments. The soil samples were passed through a $2-\mathrm{mm}$ sieve. The soil filling height and the soil volume was $140 \mathrm{~cm}$ and $54,652.17 \mathrm{~cm}^{3}$ in each soil column, respectively. For each treatment, there were three replicates. The results showed that gravel-mulching (GM), straw-mulching (SM), and diversion hole (DH) significantly decreased soil water evaporation compared with non-mulching $(\mathrm{CK})$ under the different rainfall depths $(P<0.05)$. Under rainfall of $100 \mathrm{~mm}$, the DH, GM, and SM caused an increase in the soil water content (SWC) in the 80-120 cm layer by 101.0\%, 23.6\%, and $65.5 \%$, respectively. Under rainfall of $30 \mathrm{~mm}, \mathrm{CK}$ increased SWC in the $0-40 \mathrm{~cm}$ layer, both GM and SM increased the SWC in the 0-60 cm layer, and the DH treatment allowed an increase in the $0-120 \mathrm{~cm}$ layer. Our results suggest that DH was a better measure to reduce soil evaporation and improve rainfall resource utilization, especially under high rainfall events. Our research provides scientific basis for the technology of soil deep spatiotemporal control and is of great significance to the balance and restoration of the ecological environment in the semi-arid Loess Plateau.
\end{abstract}

Keywords Diversion hole $\cdot$ Mulching $\cdot$ Soil evaporation $\cdot$ Soil water content $\cdot$ Soil column experiment

\section{Introduction}

The Loess Plateau is a typical arid and semi-arid region with loess thickness of 0-350 m (Zhu et al. 2018), where the

$\overline{\text { Highlights } \cdot \text { Fish-scale pits with diversion holes can transport rapidly }}$ surface water into the deep soil layers for soil and water conservation.

- Diversion hole can reduce soil water evaporation and increase soil water content in the deep soil layer.

- Diversion hole is a better measure to improve rainfall resource utilization, especially under high rainfall events.

Yu Liu

kingliuyu@nwafu.edu.cn

1 State Key Laboratory of Soil Erosion and Dryland Farming on the Loess Plateau, Northwest A \& F University, Yangling 712100, China

2 College of Natural Resources and Environment, Northwest A \& F University, Yangling 712100, China groundwater level is low. Rainfall is almost the only source of soil water supply and most of them are heavy hard rain. The average annual precipitation is $300-500 \mathrm{~mm}$ with approximately 60-70\% falling from June to September (Li et al. 2012; Gao et al. 2014). Runoff and soil erosion occur after heavy rainfall because rainfall intensity exceeds infiltration capacity (Fang et al. 2008; Angulo-Martínez and Beguería 2009; Zhao et al. 2013; Wei et al. 2014; dos Santos et al. 2017; Chen et al. 2018). The coexistence of drought, water shortage, and soil erosion is the key factor to restrict the sustainable development of dry farming and is also the fundamental cause of ecological fragility in the Loess Plateau (Ruiz-Sánchez et al. 2005; Song et al. 2017; Shi et al. 2018).

A series of soil and water conservation engineering measures have been popularized to solve these problems, and fishscale pit is one of the most effective measures among them in semi-arid areas of Loess Plateau (Li et al. 2011; Zhang et al. 2014; Yu et al. 2017). Fish-scale pit could effectively reduce 
the surface runoff during heavy hard rain by intercepting rainwater on the soil surface to the pit and increasing water infiltration (Fu et al. 2010; Feng et al. 2018). However, fish-scale pit also increased the ineffective evaporation because of the large contact area between soil and air (Li et al. 2011). Li et al. (2018) found that the fish-scale pit without mulching experienced in jujube orchard significantly increased evaporation by $42.28 \%$ and $65.59 \%$, respectively, during the two growing seasons. Moreover, most of the fish-scale pits would be filled with sediment or destroyed by runoff in a few years (Wang et al. 2011). Meanwhile, Zhang et al. (2016a, b) found that the evaporation has increased considerably over the past 50 years by analyzing meteorological observation data from 1960 to 2010 in Dingxi, a typical semi-arid region of the Loess Plateau. Besides, Li et al. (2012) reported that the upward trend of soil potential evapotranspiration in the Loess Plateau will be more pronounced after 2050. Therefore, the key to solve the problem of soil and water erosion in the Loess Plateau region is to prevent invalid water evaporation, control rainfall runoff and realize rainfall resource utilization $(\mathrm{Hu}$ et al. 2014).

Adding mulch on soil surface is a common way to effectively reduce water loss (Chiroma et al. 2006; Wang et al. 2009, 2016; Huo et al. 2017; Fu et al. 2018). It can weaken the impact of splash erosion of raindrops on soil surface, protect soil from erosion caused by rainfall, and reduce runoff (Rees et al. 2002; Findeling et al. 2003; Gholami et al. 2013). Moreover, effectively reducing evaporation (Qin et al. 2006; Mahdavi et al. 2017) and improving soil infiltration capacity (Wang et al. 2016; Jordán et al. 2010) owing to the physical barriers, which was set on the soil surface, hindered and slowed the exchange of water and energy between soil surface and atmosphere. Li et al. (2016) found that compared with single fish-scale pits, the fish-scale pit with mulching significantly increased soil water storage and water compensation in jujube orchard owing to the increase of water infiltration and the decrease of evaporation. Gravel and straw are widely used as cover materials in the Loess Plateau (Xie et al. 2010; Ma and Li 2011; Fan et al. 2014; Wang et al. 2015).

The Loess Plateau is known as "nature soil reservoir," because the deep soil layer has huge storage capacity for water (Zhu 2006). However, factors such as less rainfall, more runoff, high evaporation intensity, and excessive soil water depletion by vegetation of the deep soil moisture may result in a dried soil layer (Jipp et al. 1998; Chen et al. 2008; Wang et al. 2018). Sun et al. (2018) found that long-term cultivation of alfalfa pastures seriously consumed the deep soil water. This process of soil water deficit of alfalfa pastures was obviously aggravated after 4 years of planting. Therefore, another way for improving rainfall efficient utilization should concentrate on reducing runoff on the slope, and quickly transporting and storing the surface water into deep soil, thereby reducing the evaporation loss of surface layer, giving full play to the role of "soil reservoir."

Previous studies found that the mixture of the irrigated water and fertilizer flows into the pits in the management of apple orchard in northern China, which is useful for absorbed of apple roots (Zhao et al. 2014a, b). However, fewer researches have discussed the way of rapidly transporting surface water into the deep soil layers for soil and water conservation, whether it can increase the water content in the deep soil layers and reduce the ineffective evaporation is still a scientific problem to be solved. In this context, soil column simulation experiments were conducted. The major objectives and purposes of this research were to (a) determine the effects of mulch and diversion hole measures on soil evaporation under different rainfall intensity, (b) analyze the effects of mulch and diversion hole measures on the water distribution in a loessial soil under different rainfall intensity, and (c) try to find the more suitable water conservation measure for rainfall efficient utilization and the technology of soil deep spatiotemporal control in the Loess Plateau.

\section{Material and Methods}

\subsection{Soil and Experimental Equipment}

The soil used in this study is the loessial soil and was collected from Nangou Village, Ansai County, Yan'an City, Shaanxi Province, China $\left(109^{\circ} 19^{\prime} \mathrm{E}, 36^{\circ} 51^{\prime} \mathrm{N}\right)$. The experiment was carried out in the Institute of Soil and Water Conservation in Yang Ling District, Shaanxi Province, China. The soil samples were air-dried at room temperature, crushed manually, and then passed through a 2-mm sieve. The soil collected from field was high on soil spatial heterogeneity. Difference in soil pore distribution was obvious owing to the coarse fragments which could cause preferential flow in the process of water infiltration and redistribution. We sieved the soil and removed the coarse fragments for the homogeneity of soil. The particle composition of the treated soil was analyzed by laser particle size analyzer; the soil basic physical properties are shown in Table 1. The soil columns consist of column bodies that were made of PE (polyethylene) material, and plugs were made of PVC (polyvinyl chloride) (Fig. 1). The size of the column was $150 \mathrm{~cm}$ in height and $22.3 \mathrm{~cm}$ in internal diameter, the soil filling height was $140 \mathrm{~cm}$, and the total volume of the soil in each soil column was $54,652.17 \mathrm{~cm}^{3}$. White gauzes were placed at the bottom of the column before the soil columns were packed with treated soil, and Vaseline was uniformly daubed on the inner wall of the soil column to eliminate the effect of wall dominant flow. The soil bulk density in columns was $1.3 \mathrm{~g} \mathrm{~cm}^{-3}$ after packing, the soil filling way was layered filling with a thickness of $5 \mathrm{~cm}$ each time, and it is necessary to fluffed in the end of each layer to avoid the changes of soil structural and hydrodynamic between layers. The 
Table 1 Physical properties of the experimental soil

\begin{tabular}{|c|c|c|c|c|c|}
\hline Soil type & $\begin{array}{l}\text { Sand content } \\
(\%) \\
(0.02-2 \mathrm{~mm})\end{array}$ & $\begin{array}{l}\text { Silt content }(\%) \\
(0.002- \\
0.02 \mathrm{~mm})\end{array}$ & $\begin{array}{l}\text { Clay content } \\
(\%) \\
(<0.002 \mathrm{~mm})\end{array}$ & Soil texture & $\begin{array}{l}\text { Soil bulk } \\
\text { density } \\
\left(\mathrm{g} \mathrm{cm}^{-3}\right)\end{array}$ \\
\hline $\begin{array}{c}\text { Loessial } \\
\text { soil }\end{array}$ & $60.61 \pm 1.68$ & $20.51 \pm 0.69$ & $18.88 \pm 0.99$ & $\begin{array}{c}\text { Sand clay } \\
\text { loam }\end{array}$ & $1.20 \pm 0.75$ \\
\hline
\end{tabular}

Standard deviations of the means $(n=3)$ are presented as \pm values measuring tubes of TDR (TRIME-PICO IPH/T3, IMKO, Germany) were installed during the soil packing process.

\subsection{Experiment Design}

Four treatments were set in this experiment, including non-mulching (CK), gravel-mulching (GM), strawmulching (SM), and diversion hole (DH). For each treatment, there were three replicates. Gravel $(1-2.5 \mathrm{~cm}$ in diameter, $1.34 \mathrm{~kg}$ weight, and $1.5 \mathrm{~cm}$ thick in final) and maize straw $(5-7 \mathrm{~cm}$ in length, $0.07 \mathrm{~kg}$ weight and $2.7 \mathrm{~cm}$ thick in final) were used to cover the soil in the GM and $\mathrm{SM}$ treatments, respectively. PVC tubes $(3 \mathrm{~cm}$ in diameter, $80 \mathrm{~cm}$ in length) with holes in its inner wall were placed in the center of the soil column in the DH treatment.
The size of each hole was $3 \mathrm{~mm}$ in diameter in the wall of PVC tube. The holes were set every $2 \mathrm{~cm}$ in the PVC tubes, where there were two holes in each cross section. The total number of holes was 78 in each PVC tube. There were two sprinkler processes that simulated natural rainfall in this experiment. The first sprinkler amount was $3.96 \mathrm{~kg}$ water (equal to rainfall of $100 \mathrm{~mm}$ ) and carried out on May 14, 2017 with 65 days (May 15, 2017-July $18,2017)$ of evaporation. The second was $1.12 \mathrm{~kg}$ water (equal to rainfall of $30 \mathrm{~mm}$ ) and carried out on September 21, 2017 with 25 days (September 22, 2017-October 17, 2017) of evaporation. Soil evaporation of each column was measured by using the weighing method, and the soil water content was measured by TDR every 3-5 days (Fig. 1) up to a measurement depth of $120 \mathrm{~cm}$ every
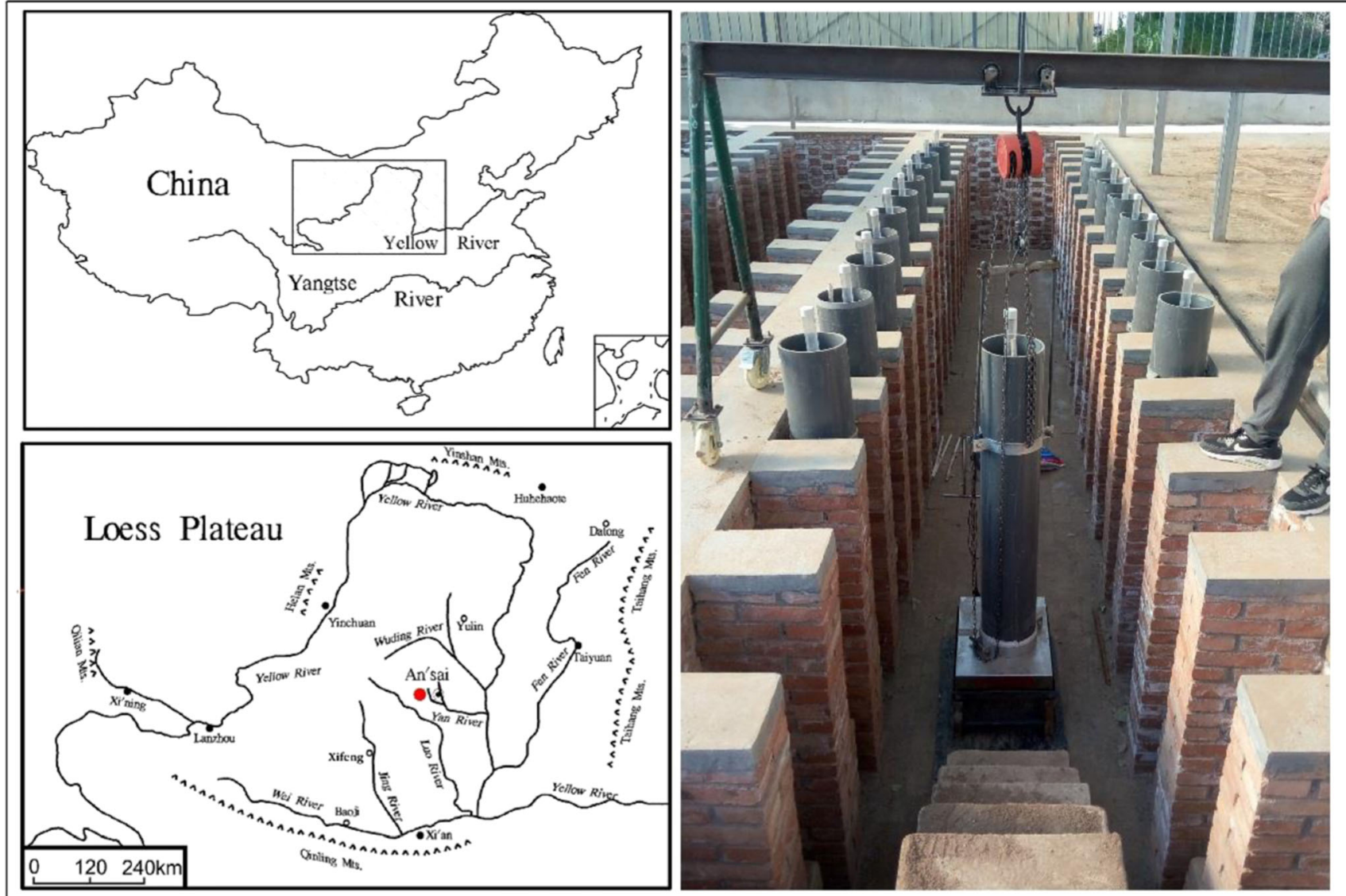

Fig. 1 Soil sample collecting site and column experiment setting up 
$10 \mathrm{~cm}$. The experiment was carried out in the shelter placed in outdoor, which could keep the experiment under natural conditions and eliminate the influence of rainfall. The initial soil water supply of each treatment before sprinkled is shown in Table 2.

\subsection{Statistical Analysis}

According to the soil water balance method, the cumulative evaporation $(E c)$ was calculated as follows:

$E c(\mathrm{~mm})=10 \times(W o-W i) /(\rho \times S),(i=3,6,9, \ldots 65)$

where $W o(g)$ is the initial weight of the soil column in the beginning of the experiment. Wi $(\mathrm{g})$ is the weight of the soil column on the $i$ th day. $\rho\left(\mathrm{g} \mathrm{cm}^{-3}\right)$ is the density of water. $S$ $\left(\mathrm{cm}^{2}\right)$ is the evaporation area of the soil column.

According to $E c$ and days of evaporation, the daily evaporation $(E d)$ was calculated as follows:

$E d(\mathrm{~mm})=\left(E c_{i}-E c_{i-d}\right) / d,(i=3,6,9, \ldots 65 ; d=3,5,6)$

where $E c_{i}(\mathrm{~mm})$ is $E c$ on the $i$ th day, $E c_{i-d}(\mathrm{~mm})$ is $E c$ on the (I $-d$ )th day, and $d$ is the evaporation days.

The comparison of the results between the different treatments would be influenced by the different initial water supply $(h$, in $\mathrm{mm})$. Therefore, we used the ratio of evaporative loss (the proportion of the final $E c$ to the initial water supply of the soil in the evaporation time ( $\mathrm{Li}$ and $\mathrm{Li} \mathrm{1991))} \mathrm{as} \mathrm{a} \mathrm{more} \mathrm{appropriate} \mathrm{index} \mathrm{to} \mathrm{illustrate}$ evaporative effects. If the ratio is high, the treatment is relatively prone to water evaporation. The evaporative loss ratio $(R)$ was calculated as follows:

$R=E c_{i} / h$

Statistical analysis was performed with SPSS 20.0. Oneway analysis of variance (ANOVA) was conducted to test the effects of each treatment on soil moisture and evaporation. Significant differences were detected using the leastsignificant difference (LSD) test at $P<0.05$. The plotting was made with Origin 8.5.

\section{Results}

\subsection{Soil Water Evaporation}

\subsubsection{Soil Daily Evaporation}

The average $E d$ in different measures under two rainfall intensity is shown in Fig. 2. The average $E d$ of CK, DH, SM, and GM was $1.48 \mathrm{~mm}, 1.31 \mathrm{~mm}, 1.17 \mathrm{~mm}$, and $0.96 \mathrm{~mm}$ under rainfall of $100 \mathrm{~mm}$, respectively, and was $0.88 \mathrm{~mm}, 0.58 \mathrm{~mm}$, $0.32 \mathrm{~mm}$, and $0.26 \mathrm{~mm}$ under rainfall of $30 \mathrm{~mm}$, respectively. The average $E d$ of different treatments under both rainfall intensity were $\mathrm{CK}>\mathrm{DH}>\mathrm{SM}>\mathrm{GM}$, and significant differences were found between the different treatments $(P<0.05)$. The changes of $E d$ in different time under two rainfall intensity are shown in Fig. 3. After rainfall of $100 \mathrm{~mm}$, the $E d$ of $\mathrm{CK}$ and DH, GM, and SM had the same trend, and the $E d$ of DH and GM was lower than that of CK and SM, respectively. The $E d$ of both CK and DH in 1-22 days was higher than in 23-65 days because the soil water decreased with time. The average $E d$ was 2.70 (1.25 to 3.99 ) $\mathrm{mm}$ in $1-22$ days and 0.82 (0.35 to 1.14$) \mathrm{mm}$ in $23-65$ days under $\mathrm{CK}, 2.28$ (0.73 to $3.59) \mathrm{mm}$ in 1-22 days, and 0.79 (0.48 to 1.13$) \mathrm{mm}$ in 23 65 days under DH. The average $E d$ was 0.96 (0.62 to 1.33) mm under GM, and 1.17 (0.72 to 1.60$) \mathrm{mm}$ under SM (Fig. 3a). After rainfall of $30 \mathrm{~mm}$, the average $E d$ of CK, DH, $\mathrm{SM}$, and GM were $0.88 \mathrm{~mm}, 0.58 \mathrm{~mm}, 0.32 \mathrm{~mm}$, and $0.26 \mathrm{~mm}$, respectively. The $E d$ decreased with the increase of evaporation days with a larger reduction rate in the first 7 days. The difference test showed that there were significant differences $(P<0.05)$ between DH and CK except for evaporation in 0-3 days and 20-25 days, and compared with CK, both the GM and SM significantly decreased the evaporation during the whole evaporation process $(P<0.05)$ (Fig. $3 b)$.

\subsubsection{Soil Cumulative Evaporation}

The changes of $E c$ in different measures under two rainfall intensity are shown in Fig. 4. After rainfall of $100 \mathrm{~mm}$, the $E c$ of CK, DH, SM, and GM in 65 days were $96.46 \mathrm{~mm}$, $85.43 \mathrm{~mm}, 75.86 \mathrm{~mm}$, and $62.39 \mathrm{~mm}$, respectively. Compared with CK, the GM and SM decreased evaporation
Table 2 The initial soil water supply of each treatment

\begin{tabular}{|c|c|c|c|c|}
\hline \multirow[t]{2}{*}{ Rainfall } & \multicolumn{4}{|c|}{ Initial soil water content (mm) } \\
\hline & GM & SM & DH & CK \\
\hline $100 \mathrm{~mm}$ & $200.08 \pm 25.00$ & $196.15 \pm 12.60$ & $186.91 \pm 12.66$ & $182.97 \pm 20.78$ \\
\hline $30 \mathrm{~mm}$ & $210.69 \pm 8.26$ & $180.02 \pm 5.24$ & $178.07 \pm 4.87$ & $160.35 \pm 8.76$ \\
\hline
\end{tabular}

Standard errors of the means $(n=3)$ are presented as \pm values

$G M$ gravel-mulching, $S M$ straw-mulching, $D H$ diversion hole, $C K$ non-mulching 


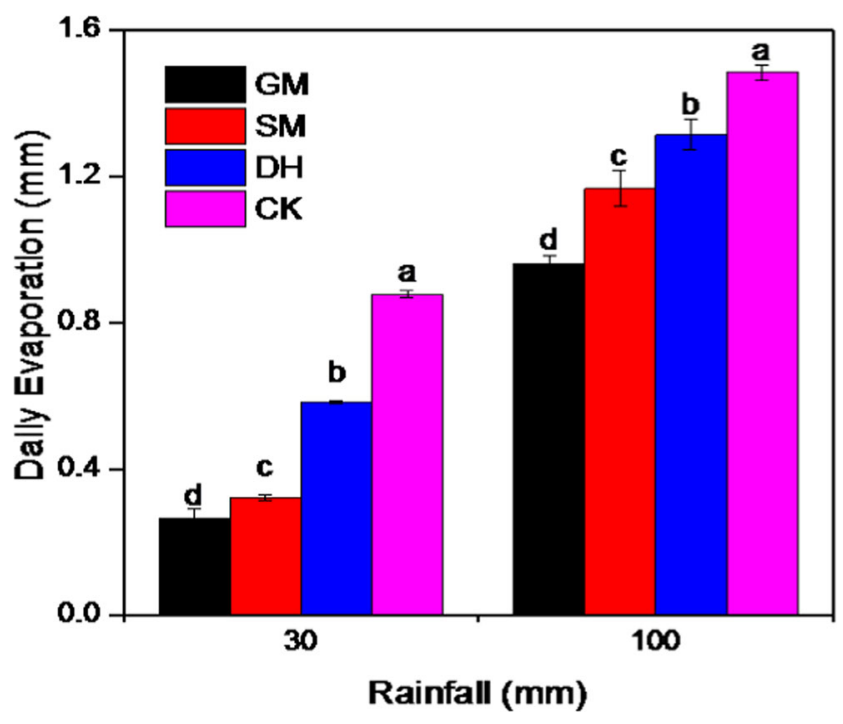

Fig. 2 The average daily evaporation of different treatments under two rainfall intensity. Date were presented as the means $(n=3) \pm \mathrm{SD}$. All raw data were compared using single-factor variance analysis method. Different letters indicate significant difference (LSD) among the treatments at $P<0.05$. CK non-mulching, GM gravel-mulching, SM strawmulching, DH diversion hole

by $35.32 \%$ and $21.36 \%(P<0.05)$, respectively, and the $\mathrm{DH}$ decreased evaporation by $11.44 \%(P<0.05)$. However, no significant effects were observed in $0-9$ days, and there was significant difference among different treatments in 12 65 days $(P<0.05)$ (Fig. 4 a). After rainfall of $30 \mathrm{~mm}$, the $E c$ of CK, DH, SM, and GM in 0-25 days were $21.95 \mathrm{~mm}$, $14.59 \mathrm{~mm}, 8.03 \mathrm{~mm}$, and $6.59 \mathrm{~mm}$, respectively. Compared to $\mathrm{CK}$, the GM and SM significantly decreased evaporation by $69.97 \%$ and $63.44 \%(P<0.05)$, respectively, the DH decreased evaporation by $33.55 \%(P<0.05)$, whereas no significant difference in 0-3 days, and compared with $\mathrm{CK}$, all the

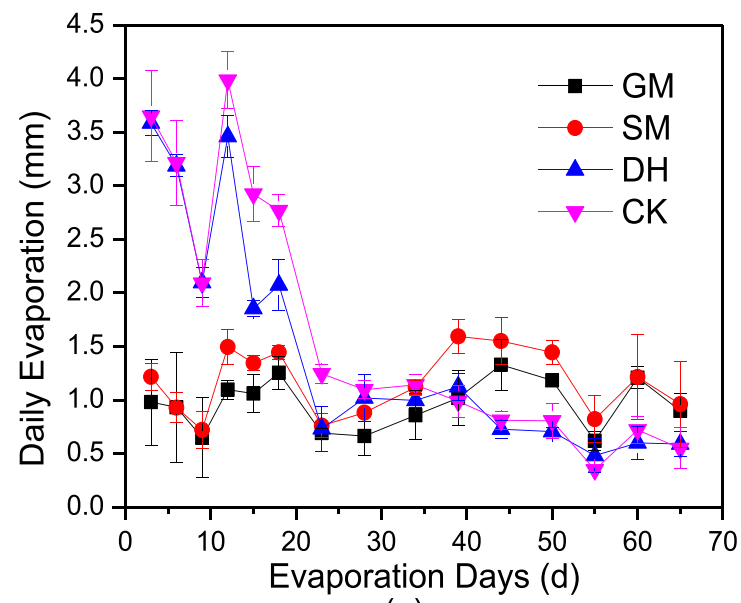

(a)

Fig. 3 a Changes of the daily evaporation under rainfall of $100 \mathrm{~mm}$. b Changes of the daily evaporation under rainfall of $30 \mathrm{~mm}$. Date were presented as the means $(n=3) \pm \mathrm{SD}$. All raw data were compared using
SM, GM, and DH significantly decreased the evaporation in $7-25$ days $(P<0.05)$ (Fig. 4 b).

\subsubsection{Soil Evaporative Loss Ratio}

Compared with CK, the DH, SM, and GM decreased the soil evaporative loss ratio by $12.82 \%, 25.08 \%$, and $38.83 \%$ after rainfall of $100 \mathrm{~mm}$, respectively $(P<0.05)$, and decreased by $38.61 \%, 66.93 \%$, and $76.19 \%$ after rainfall of $30 \mathrm{~mm}$, respectively $(P<0.05)$. Therefore, all the $\mathrm{DH}, \mathrm{SM}$, and $\mathrm{GM}$ could reduce soil evaporation in various degree (Table 3 ).

\subsection{Soil Water Distribution}

\subsubsection{Rainfall of $100 \mathrm{~mm}$}

The treatments GM, SM, and DH had different effects on the soil water content in the different soil layers under the rainfall depth of $100 \mathrm{~mm}$ (Fig. 5). Rainfall in the first day, both the maximum value of soil water and its increment under CK, $\mathrm{GM}, \mathrm{SM}$, and $\mathrm{DH}$ appeared at $40 \mathrm{~cm}, 40 \mathrm{~cm}, 50 \mathrm{~cm}$, and $90 \mathrm{~cm}$ layers, respectively, where the maximum value of soil water content was $37.62 \%, 39.96 \%, 38.29 \%$, and $31.70 \%$, respectively, and increased by $11.74 \%, 14.33 \%, 13.07 \%$, and $11.26 \%$, respectively. All the GM, SM, and DH significantly increased the soil water content in deep soil layer; compared with CK, the GM and SM increased soil water content in $40-80 \mathrm{~cm}$ layer by $9.55 \%$ and $12.69 \%$, respectively, GM, $\mathrm{SM}$, and DH increased the water content in 80-120 cm layer by $23.59 \%, 65.45 \%$, and $101.00 \%$, respectively. With infiltrating of the soil water, the change trend of soil water distribution under $\mathrm{CK}, \mathrm{GM}, \mathrm{SM}$, and $\mathrm{DH}$ was basically the same starting from the second day. The water distribution of soil

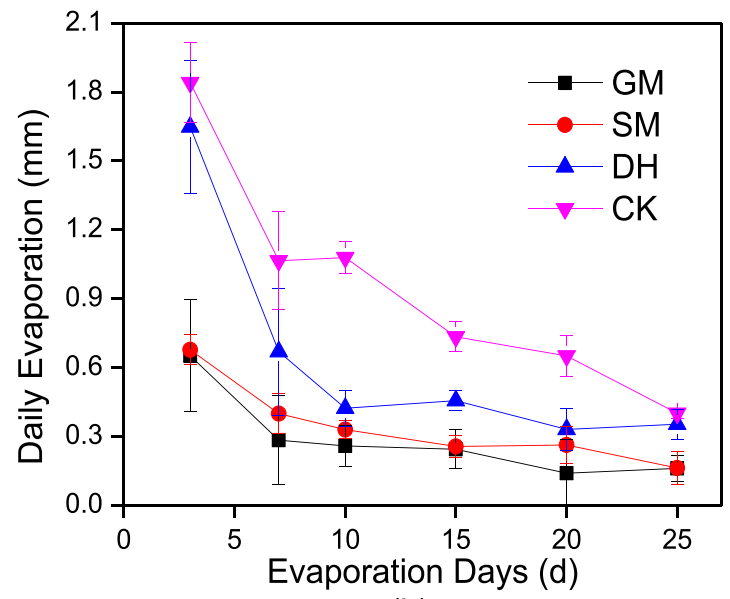

(b)

single-factor variance analysis method with the least-significant difference (LSD) test at $P<0.05$. CK non-mulching, GM gravel-mulching, SM straw-mulching, $\mathrm{DH}$ diversion hole 


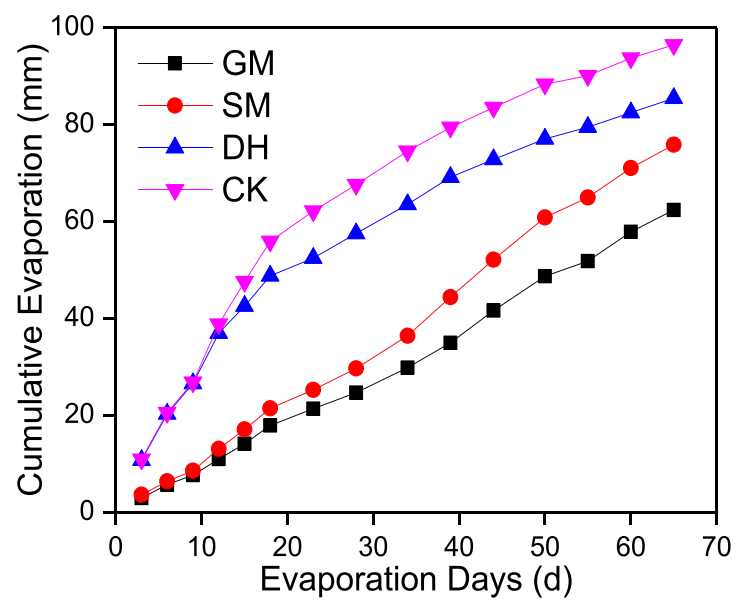

(a)

Fig. 4 a Changes of the cumulative evaporation under rainfall of $100 \mathrm{~mm}$. b Changes of the cumulative evaporation under rainfall of $30 \mathrm{~mm}$. Date were presented as the means $(n=3)$. All raw data were

profile tended to be stable under each treatment starting from the tenth day. Compared with CK, all the GM, SM, and DH increased soil water content in $0-80 \mathrm{~cm}$ layer, the GM decreased soil water content in 100-120 cm layer, and both the SM and DH decreased soil water content in 80-120 cm layer. The soil water content in each layer under both GM and SM was higher than CK starting from the 19th day, and the DH decreased water content in 0-80 cm layer, compared with CK, whereas increased water content in $80-120 \mathrm{~cm}$. Briefly, the DH increased the soil water in deep layer.

\subsubsection{Rainfall of $30 \mathrm{~mm}$}

The spatiotemporal changes of soil water distribution in the different measures under rainfall of $30 \mathrm{~mm}$ are shown in Fig. 6. The rainfall of $30 \mathrm{~mm}$ increased the water content in 0-40 $\mathrm{cm}$ layer under CK, increased the water content in 0 $60 \mathrm{~cm}$ layer under both GM and SM, and increased the water content in $0-120 \mathrm{~cm}$ layer under DH. The maximum value of soil moisture increment appeared at $20 \mathrm{~cm}$ layer under all the $\mathrm{CK}, \mathrm{GM}, \mathrm{SM}$, and $\mathrm{DH}$, where the soil water content increased by $10.44 \%, 9.63 \%, 5.59 \%$, and $3.19 \%$, respectively. The changes of soil water under CK were mainly at the $0-40 \mathrm{~cm}$

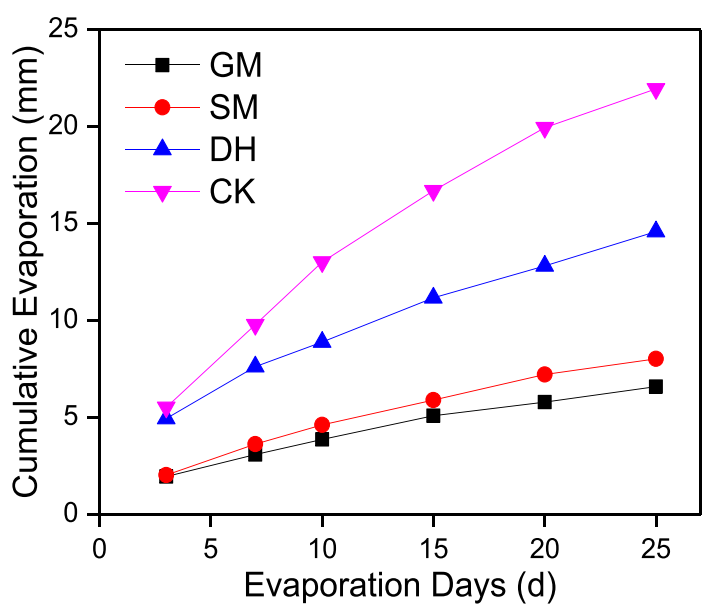

(b)

compared using single-factor variance analysis method with the leastsignificant difference (LSD) test at $P<0.05$. CK non-mulching, GM gravel-mulching, SM straw-mulching, DH diversion hole

soil layer. Both GM and SM increased the water content in 0$60 \mathrm{~cm}$ layer with evaporation time. DH increased soil water content in $0-120 \mathrm{~cm}$ layer.

\section{Discussion}

Soil evaporation potential depends on soil hydraulic conductivity and atmospheric evaporation potential (Gardner and Fireman 1958). In this experiment, the results showed that all the GM, SM, and DH could restrain soil water evaporation. Both the GM and SM could avoid direct solar radiation to consequently decrease atmospheric evaporation potential by setting physical barrier layers on the soil surface (Mahdavi et al. 2017). Based on energy balance, SM could also appreciably decrease soil evaporation by reducing the latent heat flux ( $\mathrm{Li}$ et al. 2008). GM could reduce the actual evaporation because the gravel could block the channel of water circulation by blocking the soil pores and preventing capillary water from rising (Li 2003; Zhang et al. 2016a, b), and the greater thickness of gravel, the greater its inhibition (Modaihsh et al. 1985). DH effectively decreased the water evaporation on soil surface because it could directly transport and storage water in
Table 3 Soil evaporative loss ratio under different treatments

\begin{tabular}{lllll}
\hline Rainfall & \multicolumn{4}{l}{ Soil evaporative loss ratio } \\
\cline { 2 - 5 } & GM & SM & DH & CK \\
\hline $100 \mathrm{~mm}$ & $0.2092 \pm 0.0223 \mathrm{~d}$ & $0.2562 \pm 0.0036 \mathrm{c}$ & $0.2562 \pm 0.0036 \mathrm{~b}$ & $0.3419 \pm 0.0211 \mathrm{a}$ \\
$30 \mathrm{~mm}$ & $0.0275 \pm 0.0036 \mathrm{~d}$ & $0.0382 \pm 0.0017 \mathrm{c}$ & $0.0709 \pm 0.0011 \mathrm{~b}$ & $0.1155 \pm 0.0064 \mathrm{a}$ \\
\hline Standard errors of the means $(n=3)$ are presented as \pm values. All raw data were compared using single-factor \\
variance analysis method. Different letters indicate significant difference (LSD) among the treatments at $P<0.05$
\end{tabular}



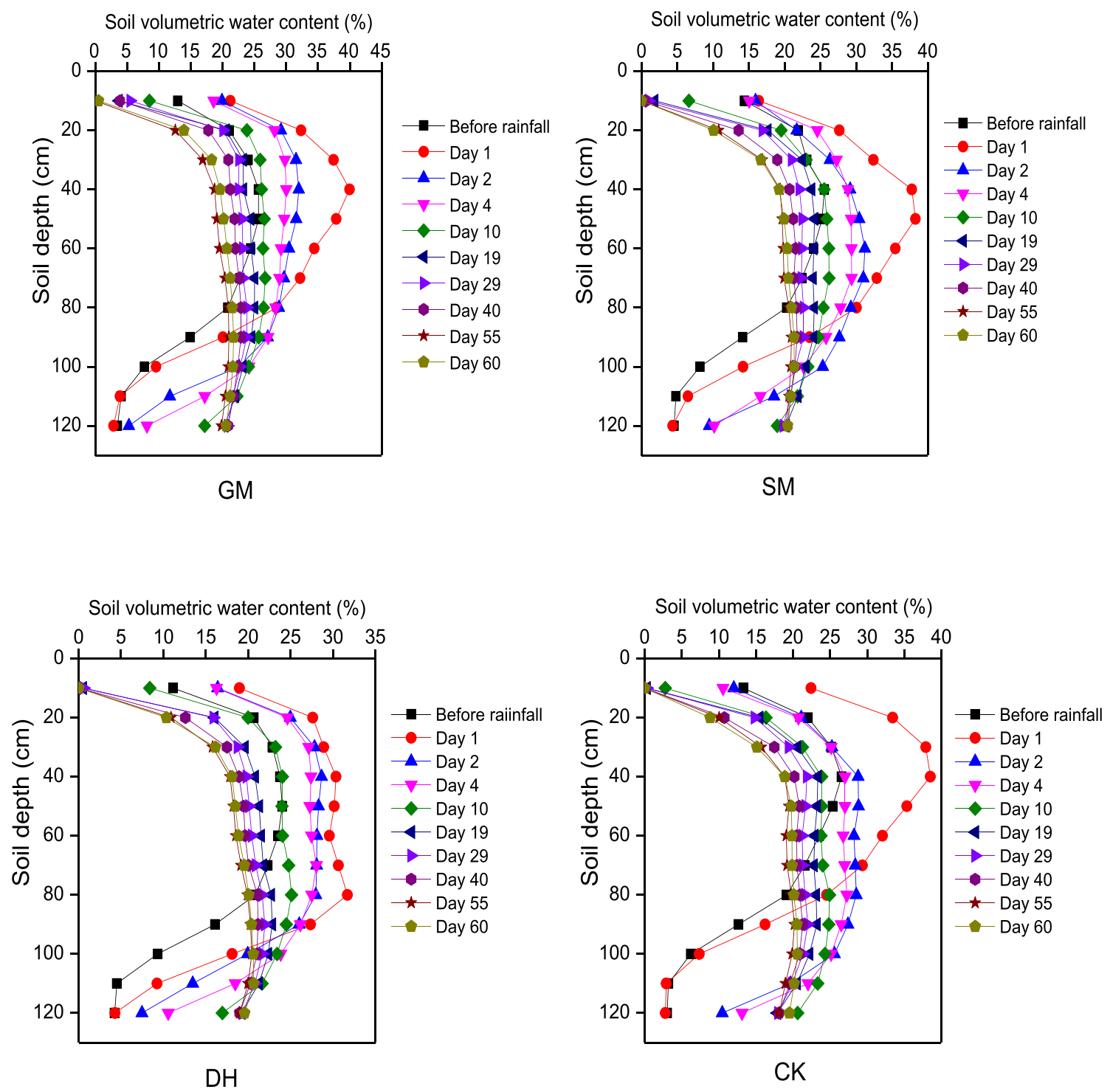

Fig. 5 Temporal and spatial changes of soil water content in each treatment under rainfall of $100 \mathrm{~mm}$. Date were presented as the means ( $n=3$ ). CK nonmulching, GM gravel-mulching, SM straw-mulching, DH diversion hole

deep soil layer. In this study, the effects of mulching measures on retraining soil water evaporation were better than $\mathrm{DH}$. Because DH had the large contact area between soil and air to increase the ineffective evaporation, the same as CK. Compared with CK, both the GM and SM had no significantly effects on $E d$ because the atmospheric evaporation potential was significantly weakened by GM and SM. However, the $E d$ under both $\mathrm{CK}$ and DH were higher at the early stage (122 days under rainfall of $100 \mathrm{~mm}$ and $1-7$ days under rainfall of $30 \mathrm{~mm}$ ) and lower at the latter stage (23-65 days under rainfall of $100 \mathrm{~mm}$ and 8-25 days under rainfall of $30 \mathrm{~mm}$ ). The soil evaporation intensity at early stage was higher, because high soil water content increased the soil hydraulic conductivity. The soil water in the lower layer moved continuously upward along the capillary pore due to the action of matrix suction, it can supplement the soil shallow layer water loss caused by evaporation. The soil evaporation intensity at latter stage was lower, because soil water content reduced by evaporation, soil hydraulic conductivity was decreased, the continuous water flow in soil pores was gradually weakened, and the replenishment of soil shallow layer water became difficult, which was insufficient to meet the evaporation requirements of the surface environment (Zribi et al. 2015).

The texture of the loessial soil is loam with large number of medium and small soil pores, which would help water infiltration, whereas it would be bad for soil water holding capacity (Wu et al. 2015; Dong et al. 2018). Soil water conductivity increased with the increase of soil water potential, which eventually led to an increase in the soil water infiltration rate (Stewart et al. 2013; Luo et al. 2018). Due to the difference of water content between upper and lower soil layers, the rainwater would infiltrate continuously with the gradients of 

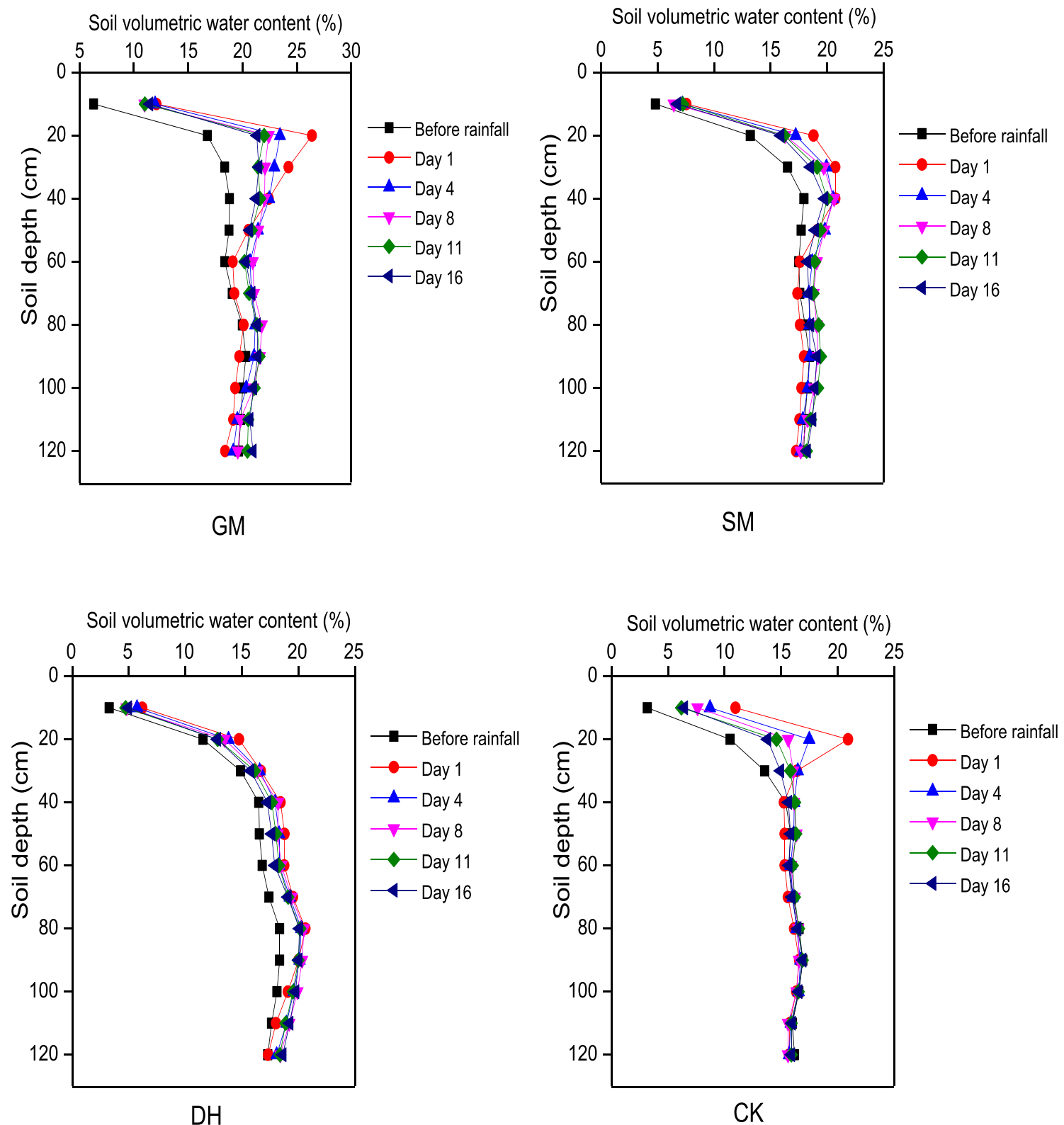

Fig. 6 Temporal and spatial changes of soil water content in each treatment under rainfall of $30 \mathrm{~mm}$. Date were presented as the means $(n=3)$. CK nonmulching, GM gravel-mulching, SM straw-mulching, DH diversion hole

gravity potential and matrix potential in the soil profile. In this study, under rainfall of $100 \mathrm{~mm}$, all the GM, SM, and DH significantly increased the soil water content in deep soil layer, compared with CK, the GM, SM, and DH increased the water content in $80-120 \mathrm{~cm}$ layer by $23.59 \%, 65.45 \%$, and $101.00 \%$, respectively. Under rainfall of $30 \mathrm{~mm}$, the changes of soil water under CK were mainly observed at the $0-40 \mathrm{~cm}$ soil layer. Both GM and SM favored an increase of the soil water content in the $0-60 \mathrm{~cm}$ layer with evaporation time, and DH increased the soil water content in the $0-120 \mathrm{~cm}$ layer. Under the heavy rainfall, water can infiltrate into the deep soil layer and increase the soil water content in different treatment. DH was more easily transport and storage rainwater to soil deep layer, because the water would infiltrate into the hole wall, whereas under the small rainfall, SM and GM cannot increase the water content in the deep soil layer under evaporation, except for $\mathrm{DH}$. The water infiltration time after rainfall under natural conditions was affected by the factors including rainfall, rainfall intensity, the properties of unsaturated zone, and soil initial water content (Rose 1996; Chiu et al. 2009; Liu et al. 2011; Ojha et al. 2017), and the evaporation had no significantly effects on the redistribution of water infiltration under a large amount of rainfall. Liu et al. (2015) found that with the increase of rainfall, there was a relatively small change of the evaporation when the rainfall is greater than $20 \mathrm{~mm}$. In general, the effects of mulching measures (especially 
gravel-mulching) on decreasing evaporation were better than $\mathrm{DH}$. Hence, DH with mulching would be the best water conservation measure, which not only directly transported and stored rainwater into the deep soil but also restrained the evaporation.

\section{Conclusions}

In general, the effects of diversion hole on limiting soil water evaporation were better than those observed non-mulching, favoring an increase of the deep soil water content. Under the high rainfall, diversion hole was better than mulching measures for increasing the water content in the deep soil layer. Our results showed that diversion hole not only reduced soil evaporation but also was a better measure to decrease runoff loss on soil surface and improve rainfall resource utilization. We suggest that diversion hole with mulch should be closely considered for use in the soil and water conservation in the Loess Plateau region.

Funding information This study was funded by the National Key Research and Development Plan of China (2016YFC0501702, 2017YFC0504504), the National Natural Science Foundation of China (41571225), and STS project of Chinese Academy of Sciences (KFJSTS-ZDTP-012).

\section{Compliance with Ethical Standards}

Conflict of Interest The authors declare that they have no conflict of interest.

Open Access This article is distributed under the terms of the Creative Commons Attribution 4.0 International License (http:// creativecommons.org/licenses/by/4.0/), which permits unrestricted use, distribution, and reproduction in any medium, provided you give appropriate credit to the original author(s) and the source, provide a link to the Creative Commons license, and indicate if changes were made.

\section{References}

Angulo-Martínez M, Beguería S (2009) Estimating rainfall erosivity from daily precipitation records: a comparison among methods using data from the Ebro Basin (NE Spain). J Hydrol 379(1-2):111-121. https://doi.org/10.1016/j.jhydrol.2009.09.051

Chen HS, Shao MA, Li YY (2008) Soil desiccation in the Loess Plateau of China. Geoderma. 143(1-2):91-100. https://doi.org/10.1016/j. geoderma.2007.10.013

Chen H, Zhang XP, Abla M, Lü D, Yan R, Ren QF, Ren ZY, Yang YH, Zhao WH, Lin PF, Liu BY, Yang XH (2018) Effects of vegetation and rainfall types on surface runoff and soil erosion on steep slopes on the Loess Plateau, China. Catena 170:141-149. https://doi.org/ 10.1016/j.catena.2018.06.006

Chiroma AM, Folorunso OA, Alhassan AB (2006) Soil water conservation, growth, yield and water use efficiency of sorghum as affected by land configuration and wood-shavings mulch in semi-arid northeast Nigeria. Exp Agric 42(2):199-216. https://doi.org/10.1017/ S0014479705003376
Chiu ACF, Zhu W, Chen XD (2009) Rainfall infiltration pattern in an unsaturated silty sand. J Hydrol Eng 14(8):882-886. https://doi.org/ 10.1061/(ASCE)1084-0699(2009)14:8(882)

Dong WC, Cui S, Fu Q, Wang QJ, Cao CP (2018) Modelling soil solute release and transport in run-off on a loessial slope with and without surface stones. Hydrol Process 32(10):1391-1400. https://doi.org/ 10.1002/hyp. 11497

dos Santos JCN, de Andrade EM, Medeiros PHA, Guerreiro MJS, de Queiroz Palácio HA (2017) Effect of rainfall characteristics on runoff and water erosion for different land uses in a tropical semiarid region. Water Resour Manag 31(1):173-185. https://doi.org/10. 1007/s11269-016-1517-1

Fan J, Gao Y, Wang QJ, Malhi SS, Li YY (2014) Mulching effects on water storage in soil and its depletion by alfalfa in the Loess Plateau of northwestern China. Agric Water Manag 138:10-16. https://doi. org/10.1016/j.agwat.2014.02.018

Fang HY, Cai QG, Chen H, Li QY (2008) Effect of rainfall regime and slope on runoff in a gullied loess region on the Loess Plateau in China. Environ Manag 42(3):402-411. https://doi.org/10.1007/ s00267-008-9122-6

Feng TJ, Wei W, Chen LD, Keesstra SD, Yu Y (2018) Effects of land preparation and plantings of vegetation on soil moisture in a hilly loess catchment in China. Land Degrad Dev 29(5):1427-1441. https://doi.org/10.1002/ldr.2867

Findeling A, Ruy S, Scopel E (2003) Modeling the effects of a partial residue mulch on runoff using a physically based approach. J Hydrol 275(1-2):49-66. https://doi.org/10.1016/S0022-1694(03)00021-0

Fu S, Liu B, Zhang G, Lu B, Ye Z (2010) Fish-scale pits reduce runoff and sediment. Trans ASABE 53(1):157-162. https://doi.org/10. 13031/2013.29508

Fu Q, Yan PR, Li TX, Cui S, Peng L (2018) Effects of straw mulching on soil evaporation during the soil thawing period in a cold region in northeastern China. J Earth Syst Sci 127(3):33. https://doi.org/10. 1007/s12040-018-0933-4

Gao Y, Zhu XJ, Yu GR, He NP, Wang QF, Tian J (2014) Water use efficiency threshold for terrestrial ecosystem carbon sequestration in China under afforestation. Agric For Meteorol 195:32-37. https://doi.org/10.1016/j.agrformet.2014.04.010

Gardner WR, Fireman M (1958) Laboratory studies of evaporation from soil columns in the presence of a water table. Soil Sci 85(5):244-249 https://journals.lww.com/soilsci/citation/1958/05000/

Gholami L, Sadeghi SH, Homaee M (2013) Straw mulching effect on splash erosion, runoff, and sediment yield from eroded plots. Soil Sci Soc Am J 77(1):268-278. https://doi.org/10.2136/sssaj2012. 0271

Hu Q, Pan FF, Pan XB, Zhang D, Yang N, Pan ZH, Zhao PY, Tuo D (2014) Effects of a ridge-furrow micro-field rainwater-harvesting system on potato yield in a semi-arid region. Field Crop Res 166: 92-101. https://doi.org/10.1016/j.fcr.2014.06.005

Huo L, Pang HC, Zhao YG, Wang J, Lu C, Li YY (2017) Buried straw layer plus plastic mulching improves soil organic carbon fractions in an arid saline soil from Northwest China. Soil Tillage Res 165:286293. https://doi.org/10.1016/j.still.2016.09.006

Jipp PH, Nepstad DC, Cassel DK, De Carvalho CR (1998) Deep soil moisture storage and transpiration in forests and pastures of seasonally-dry Amazonia. In: Potential impacts of climate change on tropical forest ecosystems. Springer, Dordrecht, pp 255-272. https://doi.org/10.1007/978-94-017-2730-3 11

Jordán A, Zavala LM, Gil J (2010) Effects of mulching on soil physical properties and runoff under semi-arid conditions in southern Spain. Catena. 81(1):77-85. https://doi.org/10.1016/j.catena.2010.01.007

Li XY (2003) Gravel-sand mulch for soil and water conservation in the semiarid loess region of northwest China. Catena. 52(2):105-127. https://doi.org/10.1016/S0341-8162(02)00181-9

Li KY, Li YS (1991) Soil evaporation behaviors under the different water supplies on the Loess Plateau. Agric Res Arid Areas 3:77-84 (in 
Chinese). http://kns.cnki.net $/ \mathrm{kcms} /$ detail $/$ detail.aspx? dbcode $=$ CJFD\&filename $=$ GHDQ $199103011 \&$ dbname

Li QQ, Chen YH, Liu MY, Zhou XB, Yu SL, Dong BD (2008) Effects of irrigation and straw mulching on microclimate characteristics and water use efficiency of winter wheat in North China. Plant Product Sci 11(2):161-170. https://doi.org/10.1626/pps.11.161

Li P, Zhu QK, Zhao LL, Chang C, Zhou Y (2011) Soil moisture of fishscale pit during rainy season in loess hilly and gully region. Trans Chin Soc Agric Eng 27(7):76-81 (in Chinese). https://doi.org/10. 3969/j.issn.1002-6819.2011.07.013

Li Z, Zheng FL, Liu WZ (2012) Spatiotemporal characteristics of reference evapotranspiration during 1961-2009 and its projected changes during 2011-2099 on the Loess Plateau of China. Agric For Meteorol 154:147-155. https://doi.org/10.1016/j.agrformet.2011. 10.019

Li HC, Gao XD, Zhao XN, Wu PT, Li LS, Ling Q, Sun WH (2016) Integrating a mini catchment with mulching for soil water management in a sloping jujube orchard on the semiarid Loess Plateau of China. Solid Earth 7(1):167-175. https://doi.org/10.5194/se-7-1672016

Li HC, Zhao XN, Gao XD, Ren KM, Wu PT (2018) Effects of water collection and mulching combinations on water infiltration and consumption in a semiarid rainfed orchard. J Hydrol 558:432-441. https://doi.org/10.1016/j.jhydrol.2018.01.052

Liu H, Lei TW, Zhao J, Yuan CP, Fan YT, Qu LQ (2011) Effects of rainfall intensity and antecedent soil water content on soil infiltrability under rainfall conditions using the run off-on-out method. J Hydrol 396(1-2):24-32. https://doi.org/10.1016/j.jhydrol. 2010.10 .028

Liu XP, He YH, Zhang TH, Zhao XY, Li YQ, Zhang LM, Wei SL, Yun JY, Yue XF (2015) The response of infiltration depth, evaporation, and soil water replenishment to rainfall in mobile dunes in the Horqin Sandy Land, Northern China. Environ Earth Sci 73(12): 8699-8708. https://doi.org/10.1007/s12665-015-4125-0

Luo YX, Li H, Ding WQ, Hu FN, Li S (2018) Effects of DLVO, hydration and osmotic forces among soil particles on water infiltration. Eur J Soil Sci 69(4):710-718. https://doi.org/10.1111/ejss.12672

Ma YJ, Li XY (2011) Water accumulation in soil by gravel and sand mulches: influence of textural composition and thickness of mulch layers. J Arid Environ 75(5):432-437. https://doi.org/10.1016/j. jaridenv.2010.12.017

Mahdavi SM, Neyshabouri MR, Fujimaki H, Heris AM (2017) Coupled heat and moisture transfer and evaporation in mulched soils. Catena. 151:34 48. https://doi.org/10.1016/j.catena.2016.12.010

Modaihsh AS, Horton R, Kirkham D (1985) Soil water evaporation suppression by sand mulches. Soil Sci 139(4):357-361 https://journals. lww.com/soilsci/Abstract/1985/04000/

Ojha R, Corradini C, Morbidelli R, Govindaraju RS (2017) Effective saturated hydraulic conductivity for representing field-scale infiltration and surface soil moisture in heterogeneous unsaturated soils subjected to rainfall events. Water. 9(2):134. https://doi.org/10. 3390/w9020134

Qin JT, Hu F, Zhang B, Wei ZG, Li HX (2006) Role of straw mulching in non-continuously flooded rice cultivation. Agric Water Manag 83(3):252-260. https://doi.org/10.1016/j.agwat.2006.01.001

Rees HW, Chow TL, Loro PJ, Lavoie J, Monteith JO, Blaauw A (2002) Hay mulching to reduce runoff and soil loss under intensive potato production in northwestern New Brunswick, Canada. Can J Soil Sci 82(2):249-258. https://doi.org/10.4141/S01-055

Rose DA (1996) The dynamics of soil water following single surface wettings. Eur J Soil Sci 47(1):21-31

Ruiz-Sánchez MC, Plana V, Ortuño MF, Tapia LM, Abrisqueta JM (2005) Spatial root distribution of apricot trees in different soil tillage practices. Plant Soil 272(1-2):211-221. https://doi.org/10.1007/ s11104-004-4781-4
Shi WH, Huang MB, Wu LH (2018) Prediction of storm-based nutrient loss incorporating the estimated runoff and soil loss at a slope scale on the Loess Plateau. Land Degrad Dev 29(9):2899-2910. https:// doi.org/10.1002/ldr.3028

Song XL, Gao XD, Zhao XN, Wu PT, Dyck M (2017) Spatial distribution of soil moisture and fine roots in rain-fed apple orchards employing a Rainwater Collection and Infiltration (RWCI) system on the Loess Plateau of China. Agric Water Manag 184:170-177. https://doi.org/ 10.1016/j.agwat.2017.02.005

Stewart RD, Rupp DE, Najm MRA, Selker JS (2013) Modeling effect of initial soil moisture on sorptivity and infiltration. Water Resour Res 49(10):7037-7047. https://doi.org/10.1002/wrcr.20508

Sun L, Huang Z, Cui Z, Lu R, Zhang RQ, Liu Y, Manuel LV, Jitendra A, Wei XH, Wu GL (2018) Soil water depletion in planted alfalfa pastures in an alpine pastoral area. Water. 10(11):1538. https://doi. org/10.3390/w10111538

Wang YJ, Xie ZK, Malhi SS, Vera CL, Zhang YB, Wang JN (2009) Effects of rainfall harvesting and mulching technologies on water use efficiency and crop yield in the semi-arid Loess Plateau, China. Agric Water Manag 96(3):374-382. https://doi.org/10.1016/j.agwat. 2008.09.012

Wang N, Jiao JY, Jia YF, Zhang XA (2011) Soil seed bank composition and distribution on eroded slopes in the hill-gully Loess Plateau region (China): influence on natural vegetation colonization. Earth Surf Process Landf 36(13):1825-1835. https://doi.org/10.1002/esp. 2209

Wang CB, Wang H, Zhao XM, Chen BH, Wang FL (2015) Mulching affects photosynthetic and chlorophyll a fluorescence characteristics during stage III of peach fruit growth on the rain-fed semiarid Loess Plateau of China. Sci Hortic 194:246-254. https://doi.org/10.1016/j. scienta.2015.08.012

Wang J, Huang J, Zhao XN, Wu PT, Horwath WR, Li HB, Jing ZL, Chen XL (2016) Simulated study on effects of ground managements on soil water and available nutrients in jujube orchards. Land Degrad Dev 27(1):35-42. https://doi.org/10.1002/ldr.2334

Wang YQ, Shao MA, Zhu YJ, Sun H, Fang LC (2018) A new index to quantify dried soil layers in water-limited ecosystems: a case study on the Chinese Loess Plateau. Geoderma. 322:1-11. https://doi.org/ 10.1016/j.geoderma.2018.02.007

Wei W, Jia FY, Yang L, Chen LD, Zhang HD, Yu Y (2014) Effects of surficial condition and rainfall intensity on runoff in a loess hilly area, China. J Hydrol 513:115-126. https://doi.org/10.1016/j. jhydrol.2014.03.022

Wu QF, Fan J, Wang JJ (2015) Water movement and simulation of different soil textures at open pit mine in Jin-Shan-Meng adjacent region. J China Coal Soc 40(5):1134-1142. https://doi.org/10.13225/j. cnki.Jccs.2014.0690

Xie ZK, Wang YJ, Cheng GD, Malhi SS, Vera CL, Guo ZH, Zhang YB (2010) Particle-size effects on soil temperature, evaporation, water use efficiency and watermelon yield in fields mulched with gravel and sand in semi-arid Loess Plateau of northwest China. Agric Water Manag 97(6):917-923. https://doi.org/10.1016/j.agwat. 2010.01.023

Yu Y, Wei W, Chen LD, Feng TJ, Daryanto S, Wang LX (2017) Land preparation and vegetation type jointly determine soil conditions after long-term land stabilization measures in a typical hilly catchment, Loess Plateau of China. J Soils Sediments 17(1):144-156. https://doi.org/10.1007/s11368-016-1494-2

Zhang YB, Cao N, Xu XH, Zhang F, Yan F, Zhang XS, Tang XL (2014) Relationship between soil and water conservation practices and soil conditions in low mountain and hilly region of Northeast China. Chin Geogr Sci 24(2):147-162. https://doi.org/10.1007/s11769013-0620-y

Zhang Q, Wang WY, Wang S, Zhang L (2016a) Increasing trend of pan evaporation over the semiarid loess plateau under a warming 
climate. J Appl Meteorol Climatol 55(9):2007-2020. https://doi.org/ 10.1175/JAMC-D-16-0041.1

Zhang YH, Zhang MX, Niu JZ, Li HL, Xiao R, Zheng HJ, Bech J (2016b) Rock fragments and soil hydrological processes: significance and progress. Catena. 147:153-166. https://doi.org/10.1016/ j.catena.2016.07.012

Zhao G, Mu X, Wen Z, Wang F, Gao P (2013) Soil erosion, conservation, and eco-environment changes in the Loess Plateau of China. Land Degrad Dev 24(5):499-510. https://doi.org/10.1002/ldr.2246

Zhao XN, Wu PT, Gao XD, Tian L, Li HC (2014a) Changes of soil hydraulic properties under early-stage natural vegetation recovering on the Loess Plateau of China. Catena. 113:386-391. https://doi.org/ 10.1016/j.catena.2013.08.023

Zhao YG, Ma JJ, Sun XH, Guo XH (2014b) Spatial distribution of soil moisture and fine roots of apple trees under water storage pit irrigation. J Irrig Drain Eng 140(1):06013001. https://doi.org/10. 1061/(ASCE)IR.1943-4774.0000624

Zhu XM (2006) Rebuild soil reservoir is an rational approach for soil and water conservation on the loess plateau. Bull Chin Acad Sci 21(4): 320-324 (in Chinese). http://www.bulletin.cas.cn/zgkxyyk/ch/ reader/view_abstract.aspx?file_no $=20060418 \&$ flag $=1$

Zhu YJ, Jia XX, Shao MA (2018) Loess thickness variations across the loess plateau of China. Surv Geophys 39:715-727. https://doi.org/ 10.1007/s10712-018-9462-6

Zribi W, Aragüés R, Medina E, Faci JM (2015) Efficiency of inorganic and organic mulching materials for soil evaporation control. Soil Tillage Res 148:40-45. https://doi.org/10.1016/j.still.2014.12.003

Publisher's Note Springer Nature remains neutral with regard to jurisdictional claims in published maps and institutional affiliations. 